James B. Bullard is an economist at the Federal Reserve Bank of St. Louis. David $H$. Kelly provided research assistance.

\title{
The FOMC in 1990: Onset of
} Recession

\section{W"} the end of a long expansion of the U.S. economy, extending almost continuously from the final quarter of 1982. In November, industrial production plummeted at an annual rate of 19.8 percent, and civilian employment fell by nearly 450,000 . The most recent estimate of real gross national product (GNP) indicates that it fell at an annual rate of 1.6 percent in the fourth quarter, and the unemployment rate climbed from 5.3 percent in June to 6.1 percent by the end of the year. By all accounts, recession had arrived."

Because the U.S. economy entered the recession in the latter portion of the year, catendar 1990 is an interesting period in which to summarize the actions of the Federal Open Market Committee (FOMC). ${ }^{2}$ By considering FOMC directives chronologically, this paper will develop a case study of monetary policymaking during the onset of a recession. Within the context of the chronology, emphasis will be placed on two types of uncertainty faced by the Committee. First, there is uncertainty about the immediate past, current and future path of real output, a primary measure of economic activity. Second, there is uncertainty about the thrust of monetary policy at a point in time, because of the various ways the policy stance can be measured. While many other considerations enter into FOMC policymaking, as will be shown, these two factors loom large in the Committee's attempts to react swiftly and effectively to economic events.

The next section provides the background for understanding Committee decision-making in 1990. It introduces the FOMC s stated objectives and illustrates briefly how the Committee might hope to bring them into balance. This back. ground is crucial to an understanding of the bulk of the paper, the chronology of FOMC decision-making contained in the subsequent section. The final portion of the paper provides summary comments.

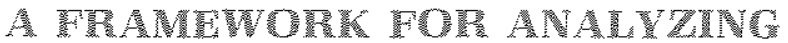

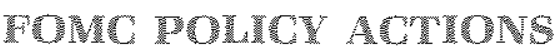

No analysis of FOMC actions can take place until some context for the decision-making is provided. ${ }^{3}$ To make sense of the subsequent chronology, it is essential to understand what
'According to the Federa Reserve Board's 1991 Monetary Policy Obiectives (p. 3). "The [U.S.] economy ... fell into recession in the latter part of 1990, and ... that recession has clearly continued into the early part of 1991 ." The National Bureau of Economic Research (NBER), which makes official decisions on dating business cycle peaks and troughs, recently announced that the expansion peaked in July 1990.
2See the shaded insert, "The Organization of the FOMC," for a description of the Committee.

"The terms "decision-making" and "policy actions" are used interchangeably in this article. 


\section{The Organization of the FOMC}

The Tederal Resenve Board of Governors consists of seven nembers, and each of these nembers hats voling rights on the lederal Open Market Committee (FOMC). The presi dent of the New York Federal Reserve Bank also is a permanent voting nember of the FOWC. The remaining 11 Tederal Reserve Bank presidents attend meetings and present views, but onty four of these 11 hate voting Trivileges at any one neeting. The voting rights are held for terms of one calendar year and rotale anong these presidents arnually.

The Conimitee typically neets eight limes: per year as it did in 1990 and sometines consults by telephone betueen scheduled metings at the end of each neeting the Committee agrees 0 a a directive to issue to The rederal Reserve Bank of NeW Yort. The direetive contains instructions for he con: diet of open natket opetations until the next regulanly scheduled neeting

A stmmary of each FOVIC neeting is re: leased to the press within d few business days following the next regutarly scheduled neeting and is subsequently published in the Federal Reserve Bulletin. The summary krown as the Record of Policy Actions of the led. eral Open Market Commitiee, is prepared by the Board staff and reviewed by the Commit tee. 11 vipicaly contams. (1) A synepsis of recent coonomic data (2) a rewlew of recent open narket operations and money narket. conditions 63. A Board staff projection of likely near-term economie developments. (4) A summary of Committee deliberations: (5) The policy directive along with a record of voles and dissenting comments, and (6) $A$ stumina y of any other business condincted. the Committee is trying to do and how it might hope to achieve its desires. These are matters of controversy in macroeconomics, and the controversy will not be resolved in this article. Instead, the following framework for understanding FOMC decision-making relies primarily on official Committee statements and simple empirical illustrations. ${ }^{4}$ Potential interpretations or conclusions are left to the reader.

\section{FOMC Monetary Policy Objectives}

The FOMC stated its goals for monetary policy in each of the eight directives it issued in 1990. Specifically, the objectives of the Committee were to foster progress toward price stability and to promote sustained real output growth. Implementation of these objectives was generally achieved by Committee-ordered intervention in the market for reserves or, in Committee parlance, by altering the ". . degree of pressure on reserve positions." ${ }^{.6}$

Committee members sometimes reconcile the two policy objectives by viewing price stability as a long-run goal and, correspondingly, sustained real output growth as a short-run goal. For instance, one summary of a Committee discussion cites some members arguing that "an eas. ing of short-run policy if such were needed to help avert a cumulative deterioration in econom. ic activity ... would not be inconsistent with the Committee's long-term commitment to price stability." " Similarly, references are sometimes made to "the Committee's long-run, anti-inflation strategy." The next section illustrates, via a simple empirical exercise, one sense in which price stability is a long-run goal.

sustanable basis, and contribute to an improved pattern of international transactions." The third objective, more ambiguous than the first two, also plays a role in the analysis to foltow

6This terminology appears in every FOMC directive in 1990. The matket for feserves is discussed in more detail below.

7March Press Release, pp. 12-13.

${ }^{8}$ August Press Release, p. 13. tained in the "Record of Policy Actions of the Federal Open Market Committee" for each meeting, released to the press shortly after the subsequent regutar meeting and later published in the Federal Reserve Bulletin and the Board's Annual Report. References to "the Record" and to press releases in this article refer to this document. 5The following sentence appears in every 1990 directive:
} 


\section{Controlling ringtan}

The FOMC's objective of controlling inflation arises out of a generally accepted proposition that the Committee has considerable influence over the long-run rate of price level change. For instance, at the February 1990 meeting "the Committee recognized that over time ... slower M2 growth would be compatible with price stability . .."s Since all Committee decisionmaking needs to be understood with this proposition in mind, some evidence on long-run inflation will be considered here. ${ }^{10}$

Following Lucas (1980), consider a version of the quantity theory of money with the key implication stated as follows: over the long term, an increase in the quantity of money, appropriately defined, is reflected in an equal and proportionate increase in the price level. ${ }^{11}$ The proposition can be investigated in an atheoretical way, since there is a wealth of available international cross-section evidence. The evidence presented below constitutes an updated version of that marshaled by Vogel (1974) and analyzed in Lucas $(1987,1980)$ and Dwyer and Hafer (1988).

Figure 1 provides a plot of 20-year averages of growth rates of M2 and the associated 20year averages of annual changes in the consumer price index for 23 OECD countries, 11 Latin American countries and Mexico. ${ }^{12}$ The period covered is 1970 to 1989 ; each country is a single observation in the figure. The quantity theory predicts that the observations will lie on a $45^{\circ}$ line, that is, that changes in money stocks and price levels will be proportional. The $45^{\circ}$ line in the diagram is adjusted to pass through the mean of the data, but it has a slope of positive one. It is not a regression line; no attempt has been made to fit the line to the data. The fact that the observations lie near the $45^{\circ}$ line

\section{Figure 1}

\section{The Quantity Theory and} International Evidence 1970-1989

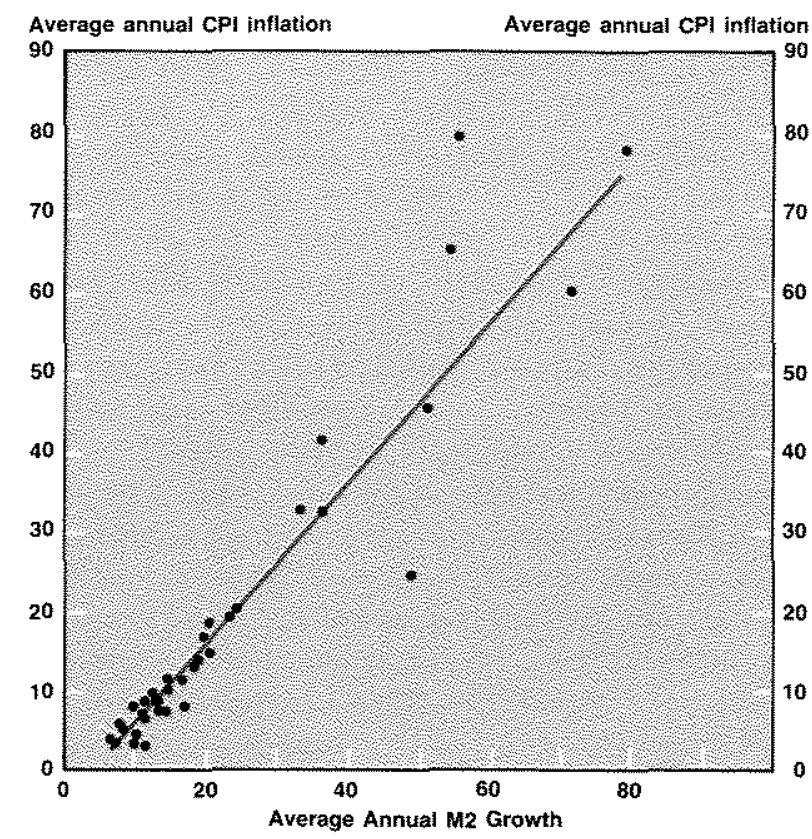

provides some evidence of the validity of the quantity theory. ${ }^{13}$

Lucas (1987) was happy enough with this type of evidence to pronounce the inflation problem "successfully solved in a scientific sense."14 The figure does seem to reflect what many economists and market participants have in mind when they think about the relationship between central bank actions and inflation. The theory appears to work surprisingly well, as the figure contains information derived from countries

\footnotetext{
9March Press Retease, p. 12.

toSee also the work on money and intlation in the $P^{*}$ model, such as Hallman, Porter and Small (1989).

For a discussion of the quantity theory and its variants, see Laidter (1985).

12The countries are: Austratia, Austria, Belgium, Brazil, Canada, Denmark, Finland, France, (West) Germany, Greece, lceland, Ireland, Italy, Japan, Norway, The Netherlands, New Zealand, Portugal, Spain, Sweden, Switzerland, Turkey, United Kingdom, United States, Argentina, Chile, Columbia, Guyana, Suriname, Paraguay, Mexico, Peru, Bolivia, Venezuela, Ecuador and Uruguay. Some observations were missing: Brazil, 1985 1989; Columbia, 1986 and 1989; Chile, 1985-1989; Guyana, Suriname, Paraguay, Peru, Bolivia and Ecuador, 1989.
}

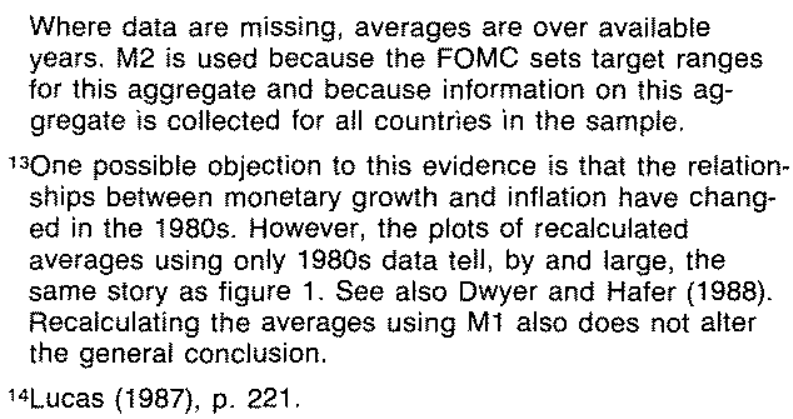
years. M2 is used because the FOMC sets target ranges for this aggregate and because information on this aggregate is collected for all countries in the sample.

130 ne possible objection to this evidence is that the relationships between monetary growth and inflation have changed in the 1980s. However, the plots of recalculated averages using only 1980 s data tell, by and large, the same story as figure 1. See also Dwyer and Hafer (1988). Recalculating the averages using $M 1$ also does not alter the general conclusion.

14Lucas (1987), p. 221. 
with very different social and economic structures. Most importantly for the purposes of analyzing FOMC decisions, the figure provides a basis for the Committee's concern about inflation because it relates inflation to money growth, and the Committee sets target ranges for certain monetary aggregates.

While low inflation countries tend to be low money growth countries, the relationship is far from exact. For instance, Japan experienced a 5.5 percent rate of annual inflation during the period with an average M2 growth rate of over 11 percent, while the U.S. experienced inflation of 6.1 percent with $\mathrm{M} 2$ growth averaging 8.3 percent per annum. ${ }^{15}$ While a few percentage points on the inflation rate is substantial by U.S. standards, it is not a lot by world standards. The good fit in the diagram is obtained by examining countries with a broad range of inflation experiences, from near zero to more than 80 percent per year. The point is that the U.S. Federal Reserve, when compared with other central banks worldwide, tends to be in the low money growth-low inflation group.

Another important consideration, emphasized by Lucas (1980), is that the FOMC's influence on inflation appears to be the product of a great many decisions over a very long time frame. The evidence presented says nothing about the relationship between money growth and inflation on a quarter-by-quarter basis. ${ }^{16}$ Thus, even when inflation control is taken very seriously, the FOMC may have considerable room to maneuver on a meeting-by-meeting basis and still meet its stated long-run inflation objective.

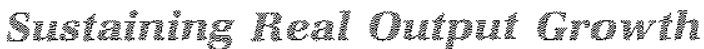

The nature of the relationship between monetary policy and real activity is controversial and remains an unresolved issue in macroeconomics. ${ }^{17}$ Nevertheless, FOMC meeting summaries indicate that Committee members believe an easier policy can mitigate declines in real output, at least in the short term. In November 1990, for instance, "the members agreed that a limited degree of easing at this juncture would provide some insurance against a deep and prolonged recession. . . ." 18 Similarly, in December, "Members noted that monetary policy had been eased ... [and thatl a limited further move would provide some added insurance in cushioning the economy against the possibility of a deepening recession. . . " At the same meeting, reference is made to "The stimulus provided by the recent easing. . . ."20 In August 1990, Committee discussion noted that "a tightening move ... might stall an already weak economic expansion." 21 Therefore, while due note is taken of the theoretical controversy, for the purposes of this article, the real effects of monetary policy are simply taken as given.

\section{The Mate of Toperas Fin Policy Actions}

The FOMC's stated short-run policy objective necessarily emphasizes the role of forecasting. The Committee must make an assessment of the likely direction of the economy in the near term if it wants to cushion changes in real output when warranted. In addition, the Committee also must assess the current and immediate past position of the economy, since reliable data on real GNP are not available for several quarters. As will become clear in the next section, however, economists have a difficult time forecasting even a few quarters ahead. By proxying the information on real GNP available to the Committee with the Blue Chip Consensus forecast, and by using only data available at the time of the meeting, an appreciation of the uncertainty the Committee faced in 1990 meeting by meeting will be developed. ${ }^{22}$

The Blue Chip Consensus is not the only indicator of the perception of economists regar. ding real activity. The Board staff prepares a forecast especially for each meeting, and that projection is probably the most relevant one

¿2The Blue Chip Economic Indicators is a monthly survey of about 50 mostly private sector economto forecasting firms. The Blue Chip forecast for a variety of economic variables is the average torecast of these firms.

\footnotetext{
15Simple measurement error is one possible reason for such discrepancies.

16 See Lucas (1980) for a method of recovering the close fit for U.S. quarterly data.

17For a recent survey, see Bianchard (1990).

${ }_{18}^{18}$ December Press Release, p. 12.

19 February Press Release, p. 12.

20February Press Release, p. 12

21October Press Release, p. 12.
} 


\section{How Much Uncertainty Exists in Forecasts of Quarterly Real GNP?}

Forecasts of quarterly changes in real GNP tend not to be very accurate, as is well known. To get some idea of the uncertainty involved, consider the forecast errors based on the Bhe Chip Consensus for the time period W/1982 to W1989.

Each month Blue Chip publishes a consensus forecast for the annualized rate of real GNP growth in the current quarter and each quarter ahead for at least one year. Although actual data are sometimes revised many years after they are first published so called bench. mark revisions), changes in teal GNP are often considered final within about three months of the end of the quarter. Taking the published forecast at the mijpoint of the quarter (e.g. February 10 for the first quar. tert and subtracting the final figure gives the forecast error at various time horizons. The mean error and the mean absolute forecast emror at these horizons are as follows $(32$ observations)

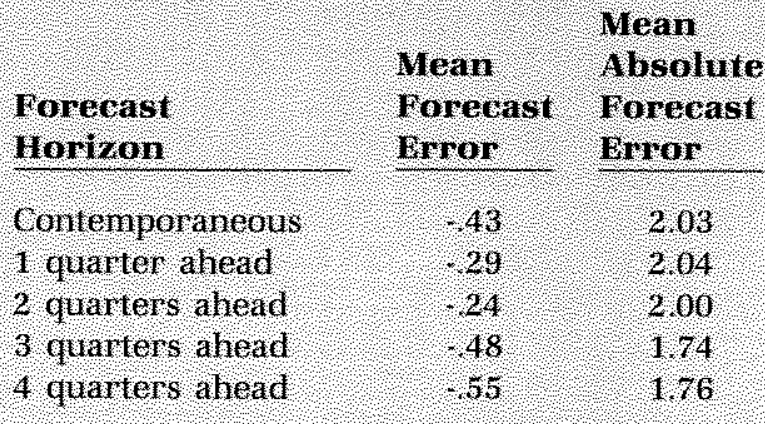

for Committee decision-making. ${ }^{23}$ Unfortunately, it is not declassified until five years after the meeting. Using the Blue Chip forecasts as a proxy for information available to the Committee is not much of a concern for the analysis to follow, however, because in every case, the qualitative description of the Board projection given in the Record of Policy Actions is consistent with the Blue Chip Consensus. Further-
Of primary concern are the relatively large mean absolute deviations. They suggest that outcomes far from what is forecast often oe: cur, as an average error at any hovizon is at least 17.4 percent. Also interesting is that, for this set of forecasts, there is at least as much uncertanty sumrounding the current quarter forecast as the fourquarter ahead forecast

The difficulty of aggregate economic fore casting will come as no surprise to many readers, and it is not hard to identify plausi ble reasons for the problem. There nay simply be considerable random variation in real activity sinilarly, it may be that real outpui reaets quite quickly to unpredictable economic and political events. In 1990, one such event stands out the Iragi invasion of Kuwait and the subsequent large variations in the price of oil In addition, all forecasts are conditional on policy, and actual policy may differ from that built in at the time of the forecast:

\footnotetext{
23According to Meitzer (1990), p. 31, "Fed forecasts of GNP

are as accurate as the forecasts from other models.

See also Karamouzis and Lombra (1989) and Meitzer (1987).

${ }^{24}$ See the shaded insert, "How Much Uncertainty Exists in Forecasts of Quarterly Real GNP?" for a description of the uncertainty surrounding these forecasts.
}

more, in only one case did the Committee's assessment differ qualitatively from that of the Board staff; that case (the October meeting) will become apparent. Finally, the forecasting difficulties discussed in detail below are not a matter of decimal points but of qualitative direction; the Blue Chip forecasts will serve to illustrate this point. ${ }^{24}$ 


\section{Measuring the Policy SEAnce}

Any summary of FOMC monetary policy actions requires some measurement of the policy stance at a point in time. One of the problems of monetary policymaking is that various measures can yield conflicting signals, sometimes making it difficult to discern the thrust of policy. Consideration in this paper will be given to four possible measures, or "indicators," of the monetary policy stance: the language of the directive, the federal funds rate, the monetary ag gregate $\mathrm{M} 2$, and total reserves. ${ }^{25}$ of these, the simplest and most straightforward measure, relied on heavily in the following chronology, is to examine the Record to find out the language of the directive. The other indicators are based on a simple analysis that associates "easing" or "tightening" with movements in measured variables.

The implementation of monetary policy typically occurs via intervention in the market for reserves, which are actively traded among banks. The interest rate in this market is the federal funds rate, and the total reserve supply is subject to control by the Federal Reserve. For a given downward-sloping demand, the Federal Reserve can increase (decrease) the federal funds rate by decreasing (increasing) the supply of total reserves. A common simple analysis relates the sum of total reserves and currency the monetary basel to measures of money such as M2 by a proportional factor greater than one known as the money multiplier. ${ }^{26}$ Generally speaking, therefore, a decrease in the federal funds rate, an increase in M2 and an increase in total reserves can be indications of easier monetary policy, while movements in the opposite directions can be indications of tighter policy. In practice things are not so clear because the demand for reserves (and also the demand for M2) may fluctuate over time, perhaps swamping the effect of a change in reserves on the federal funds rate or on M2. ${ }^{27}$

Nevertheless, because total reserves are subject to control by the Committee, they constitute a logical indicator of policy. In addition, because the Committee set target ranges for both the federal funds rate and M2 in 1990, they are also logical indicators of the policy stance. ${ }^{28}$ Generally, however, one's assessment of the policy stance at a point in time can differ depending on which indicator is used. As will be shown below, the indicators can give conflicting signals, differing not only from the language of the directive but also from each other.

The data on indicators referenced in the subsequent chronology are plotted in figures 2 through 6 . The primary reference for the federal funds rate that will be used is the weekly time series for 1990 presented in figure $2 .{ }^{29}$ The 1990 weekly series for M2 is plotted in figure 3; the annualized weekly growth rates are plotted in figure $4 .^{30}$ The interpretation of M2 is typically within the context of the target cone, which is reviewed by the Committee twice yearly and represents the FOMC's long-term target. Within the target cone, however, is some leeway to alter M2 growth rates meeting by meeting. As can be seen from figure 4, growth rates of monetary aggregates tend to be fairly noisy. The time series for total reserves in 1990 is given in figure 5 . Unfortunately, these data also tend to be noisy; in addition, the Committee does not set a target growth cone for total reserves. These facts sometimes combine to make interpretation difficult. Figure 6, however, plots the annualized intermeeting growth rates of total reserves, based on the nearest available data point (since total reserve data are biweekly).
${ }^{25}$ This list is by no means exhaustive. There are many other indicators that receive attention from economists, including various monetary aggregates, reserve components, interest rate spreads, commodity prices and so on. Reference to these alternative indicators is suppressed in this article in the interest of streamlining the discussion.

26 See Papademos and Modigliani (1990) for a recent exposition.

$27 \mathrm{n}$ the Record these fluctuations in demand are sometimes referred to as short-run technical factors.

29The range for the federal funds raie was set primarity for consultative purposes; that is, if the actual rate fluctuated persistently outside the range during an intermeeting period, the committee agreed to discuss the situation. The Committee did not set a range for the federal funds rate at its November or December meetings, saying it no longer "served [any] real purpose." See the December Press Release, pp. 15-16. Mention of the target ranges for the federal funds rate and M2 is made only to show that the Committee gives these indicators some official status. Total reserves, on the other hand, does not have such a status.

${ }^{29}$ For an assessment of this interest rate as an indicator of monetary policy and a predictor of future real sector activity, see Bernanke and Blinder (1990).

${ }^{30}$ For discussions of monetary aggregates and their relationship to real activity, see Christiano and Ljungqvist (1988) and Stock and Watson (1987). 
Figure 2

The Weekly Federal Funds Rate in 1990

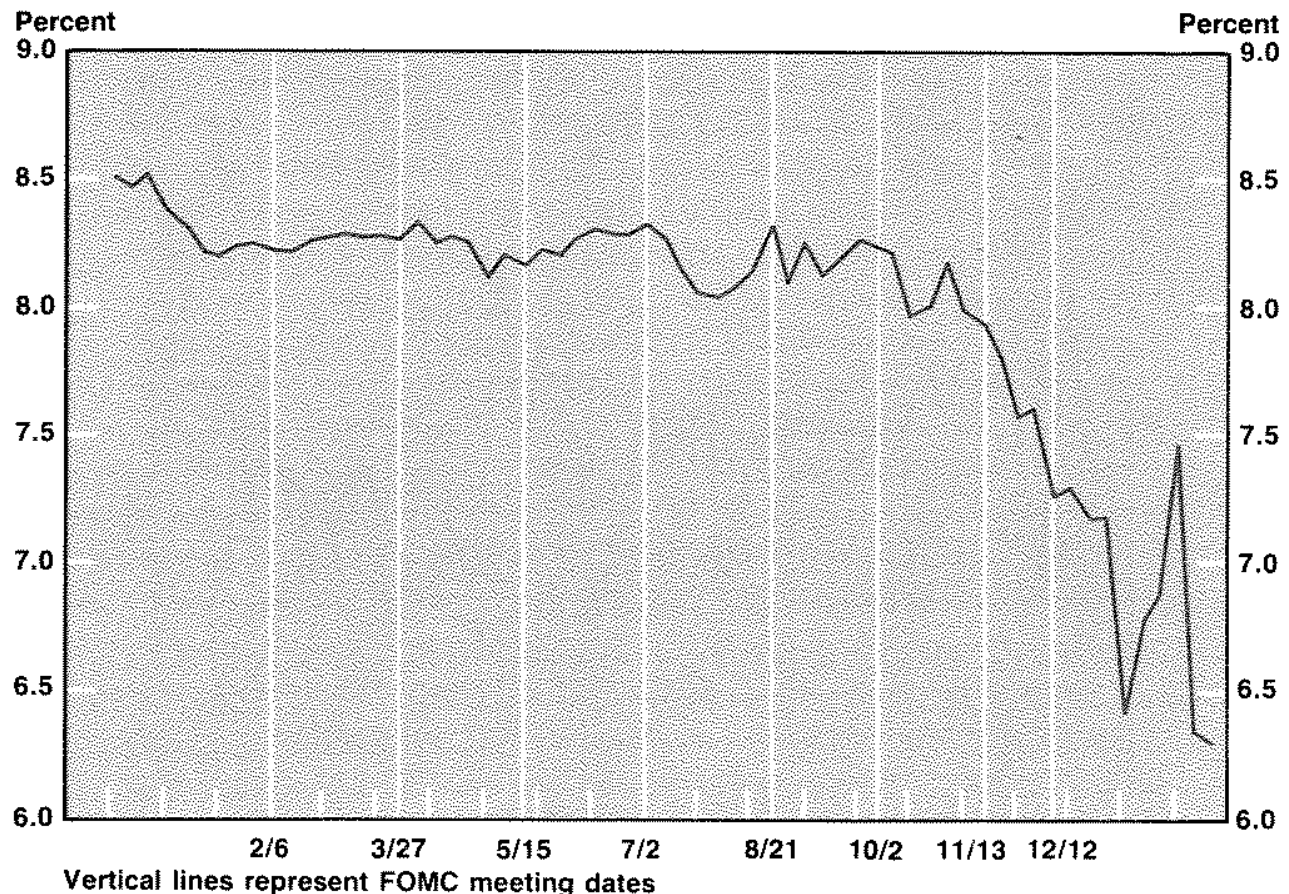

Figure 3 M2 in 1990

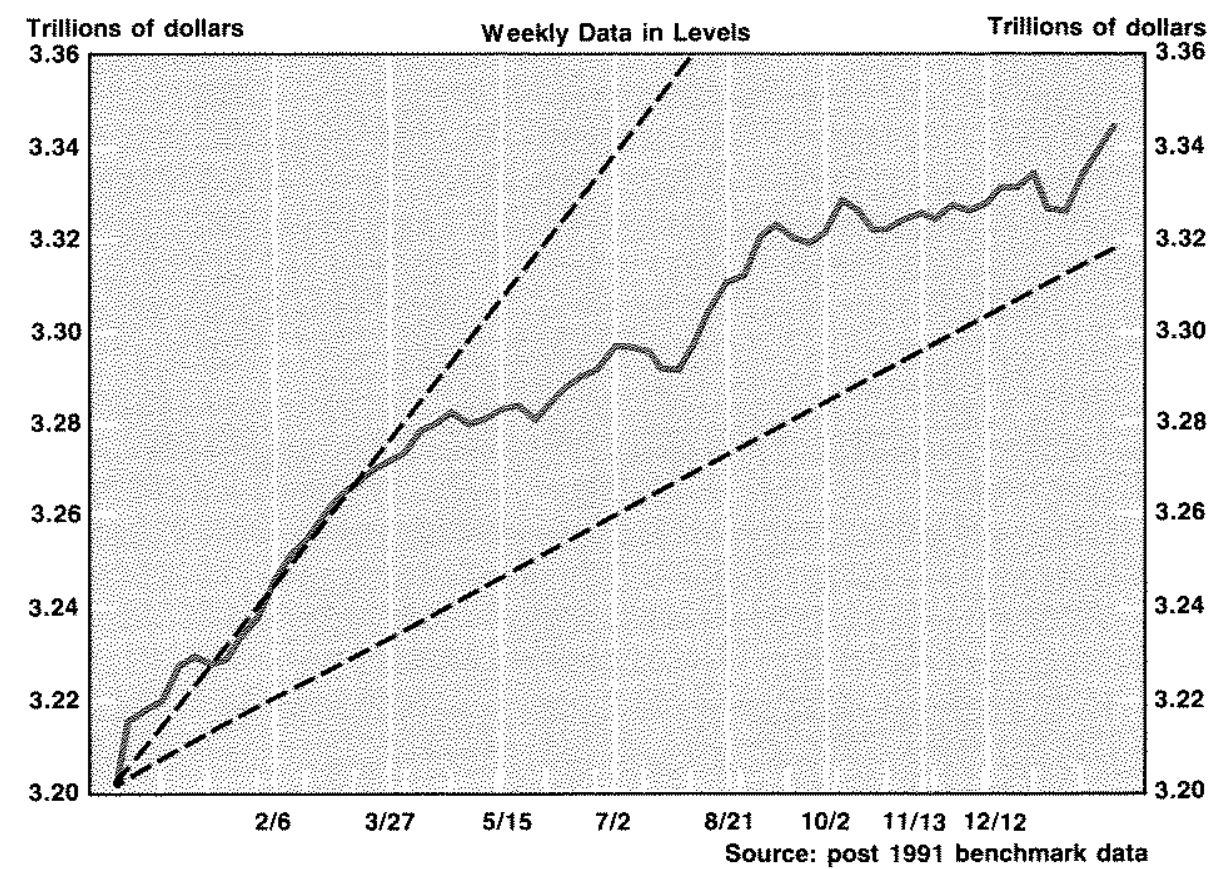

Vertical tines represent FOMC meeting dates 
Figure 4

M2 Growth in 1990

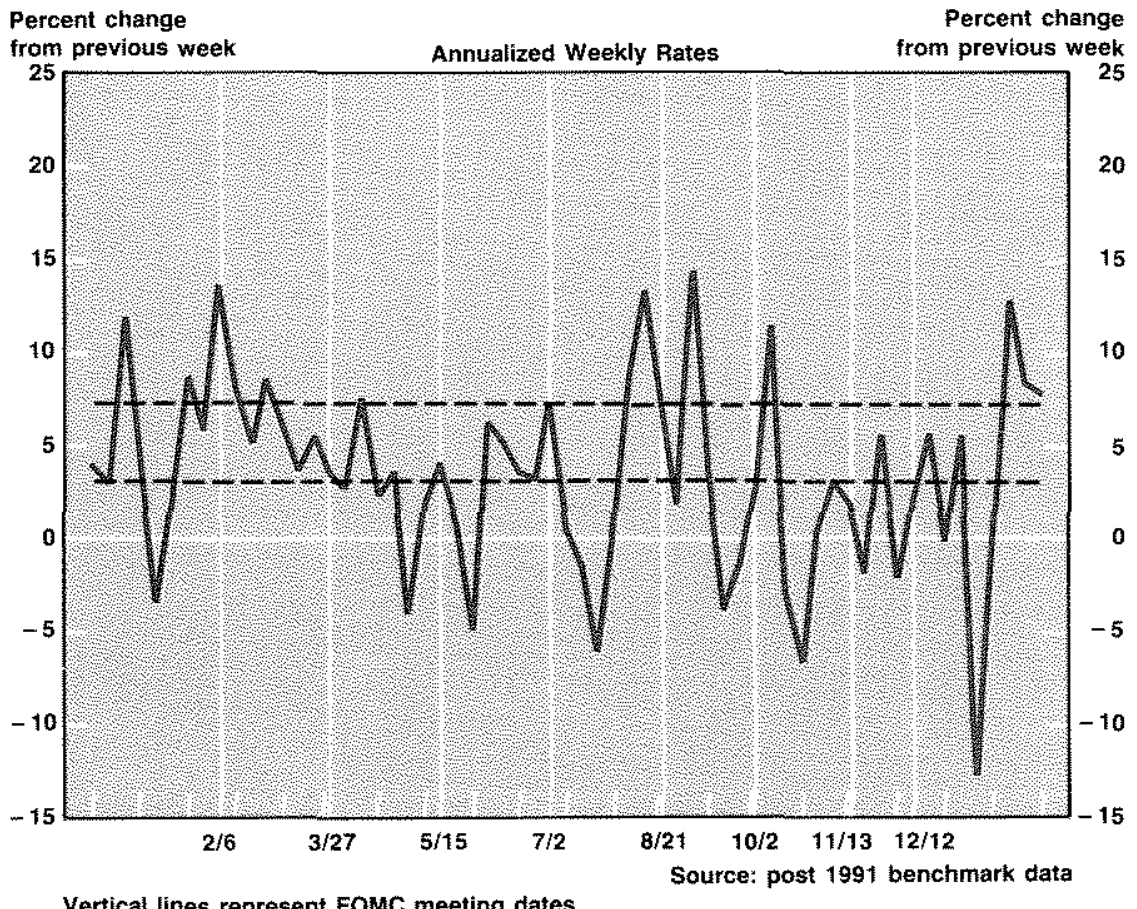

Figure 5

Total Reserves in 1990

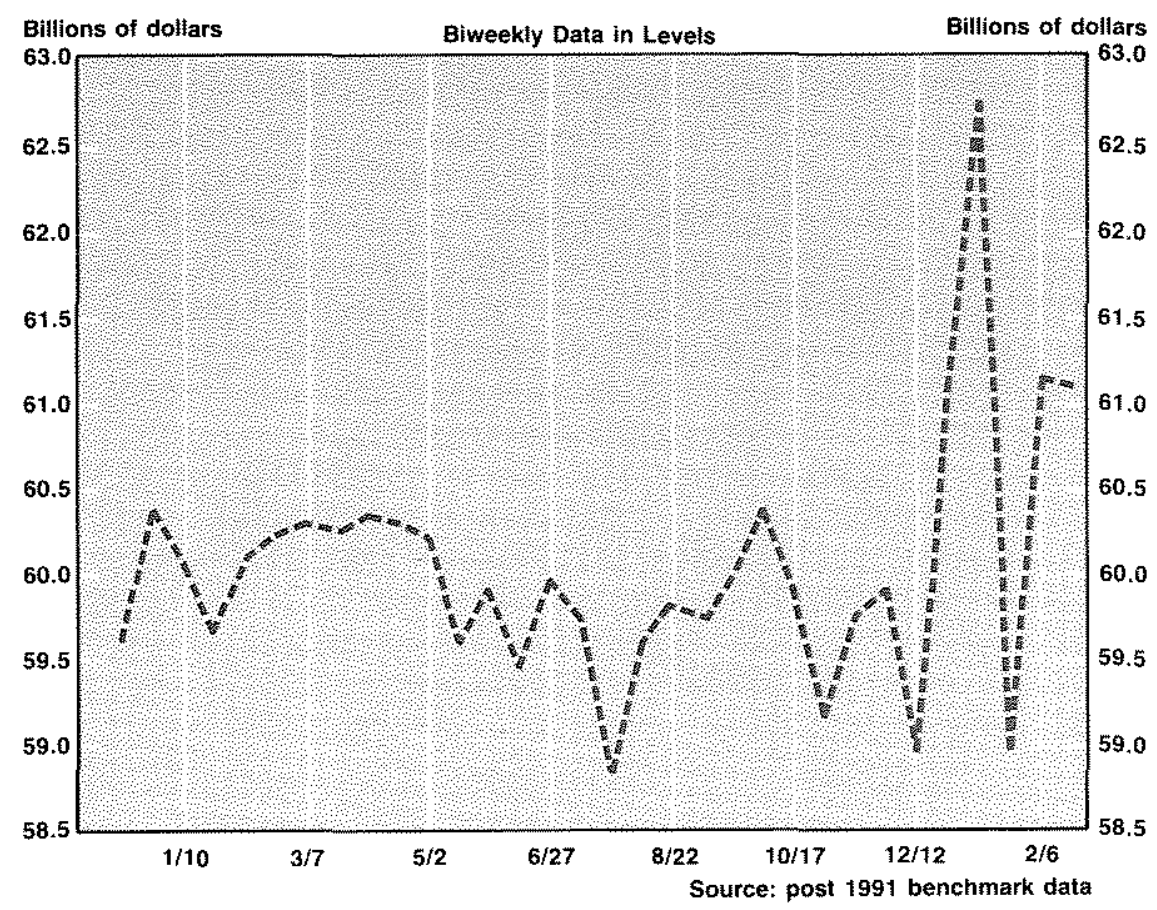




\section{Figure 6} Intermeeting Growth of Total Reserves'

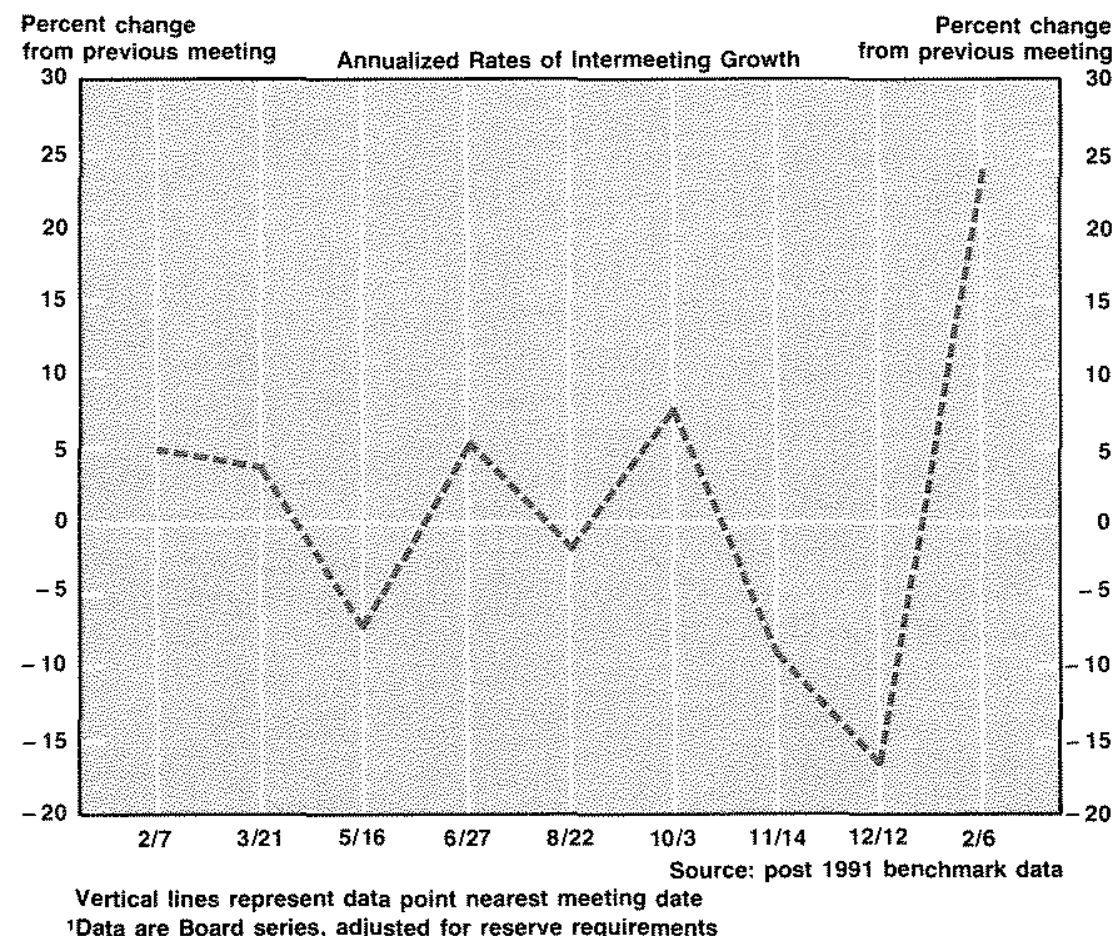

1Data are Board series, adjusted for reserve requirements

For all indicator data, vertical lines represent FOMC meeting dates.

The framework that will be used in this paper to summarize FOMC decision-making is now complete. The Committee states its major objectives in every directive, and they are to control inflation and to maintain sustained growth in real output. International evidence suggests that low inflation rates can be achieved by maintaining low rates of money growth. The real output effects of monetary policy are theoretically less certain, but summaries of Committee deliberations indicate that members believe temporary easing can mitigate downturns in economic ac tivity. pursuit of this objective requires an assessment of the current and future time path of real output, but knowing whether the incoming data signal a change in direction for the economy is complicated by lags in data releases and er. rors in even the best economic forecasts. To summarize FOMC policy actions, some measure of the monetary policy stance is required. Since various measures sometimes suggest differing interpretations of the thrust of monetary policy, several indicators will be employed.

\section{CHPONOLOGY OP POMC DECISON-WAWING MN 1990}

\section{Mecting of February 6\%, 1990}

The February meeting was one of two during 1990 when the Committee reviewed its longterm objectives for growth in the monetary aggregates. Much of the discussion focused on the growth range for M2..$^{31}$ A staff report suggested that, given the current forecasts for nominal GNP, the rate of growth of M2 in 1990 was likely to be in the "upper end of the tentative range" of 3 to 7 percent set the previous July. ${ }^{32}$ In this view, the Committee could retain "considerable leeway" to make "faster progress against inflation without impairing the forward momentum

3+ March Press Release, p. 11.

${ }^{32}$ March Press Release, p. 12. 
of the economy ..." by retaining the tentative range. ${ }^{33}$

After contemplating the staff report and other pertinent information, the Committee agreed on a range of 3 to 7 percent growth for M2 during the year, as computed from the final quarter of 1989 to the final quarter of 1990 . The range set for M3 was 2.5 to 6.5 percent, down from the 3.5-to-7.5 percent tentative range used in $1989 .{ }^{34}$ One interpretation of these growth rates is suggested by the information in figure 1 . In particular, if maintained over a long period of time, these growth rates are consistent with low aver. age rates of inflation relative to a world standard. In this sense the Federal Reserve continued to maintain its posture for preferring low inflation relative to other central banks. In fact, the Committee hoped to "signal a [continued] determination to move toward the objective of price stability." 35

The Committee also discussed policy for the period until the next meeting. The outlook for real GNP at the time of the February meeting is given in figure 7 , which illustrates the beliefs of private forecasters on February 10. In the figure, the boxes represent the most recently revised data available at the time for points in the past, plus the Blue Chip Consensus forecast at the time for points in the future. The crosses represent the evolution of real GNP based on revised data and the Blue Chip Consensus forecast for 1991 and 1992 available as of April 1991. ${ }^{36}$

Considering the figure from the perspective at the time, real GNP growth appeared to be near 3 percent in the third quarter of 1989 , but approached zero in the fourth quarter. The forecast called for increasing rates of growth throughout 1990. In retrospect, the second and third quarters of 1989 were actually much weaker than they appeared at the time. ${ }^{37}$ While the prediction that the economy would rebound slightly in the first quarter of 1990 appears by

\footnotetext{
33March Press Release, p. 12.

${ }^{34}$ According to the Record, the change in the $M 3$ fange was viewed as consistent with an unchanged $M 2$ range for

"fechnical reasons." See the March Press Release, p. 13.

${ }^{35}$ March Press Release, p. 12.

${ }^{36}$ Blue Chip forecasts are released on the 10th of each month.

37The problem of data revision is acute, and an important consideration to keep in mind is that the view of the data today is tself subject to revision in the future. See also Mankiw and Shapiro (1986).
}

present estimates to have been correct, the private sector forecasts of a generally strengthening economy throughout 1990 turned out to be erroneous.

The Board staff projections were qualitatively consistent with the private forecasts at the time of the February meeting, as they predicted that "the economy was likely to expand relatively slowly over the next several quarters." ${ }^{\prime 38}$ The FOMC membership generally concurred with this view, seeing "continuing growth in economic activity [as] a reasonable expectation for the year ahead" and "some assurance that the expansion was no longer weakening and indeed that a modest acceleration might be under way. ..." 39

Among the plethora of other information considered by the FOMC in February, the Record indicates that, internationally, Japan was experiencing strong growth in real GNP and that, while Germany, Italy and France appeared to be gain. ing strength, the United Kingdom and Canada remained sluggish. The trade-weighted value of the dollar in terms of foreign currencies had recently fallen, and most of the depreciation was against the German mark. U.S, civilian unemployment was unchanged at 5.3 percent. ${ }^{\text {to }}$

At the conclusion of the meeting, the FOMC issued a policy directive to "maintain the existing degree of pressure on reserve positions." 41 The policy for possible adjustments during the intermeeting period was to be symmetric, with no bias toward tightening or easing. ${ }^{42}$

\section{Meeting of March $2 \%, 1990$}

Considering figure 2, policy was indeed steady in the six weeks following the February meeting, as the federal funds rate remained unchanged at about 8.25 percent through late March. While figure 3 shows that M2 was slightly above the upper end of the target cone during
38March Press Release, p. 6.

${ }^{39}$ March Press Release, p. 7. The Committee also discussed the risk of a downtum

${ }^{40}$ March Press Release, pp. $1-4$.

${ }^{41}$ March Press Release, p. 21.

42March Press Release, p. 18. The Committee sometimes issues asymmetric directives, which augment the basic directive by stating a direction of bias. In some cases, the Committee ties the direction of bias to data or other information forthcoming during the intermeeting period. 


\section{Figure 7 \\ Private Forecasters' View of Real Output, February 1990}

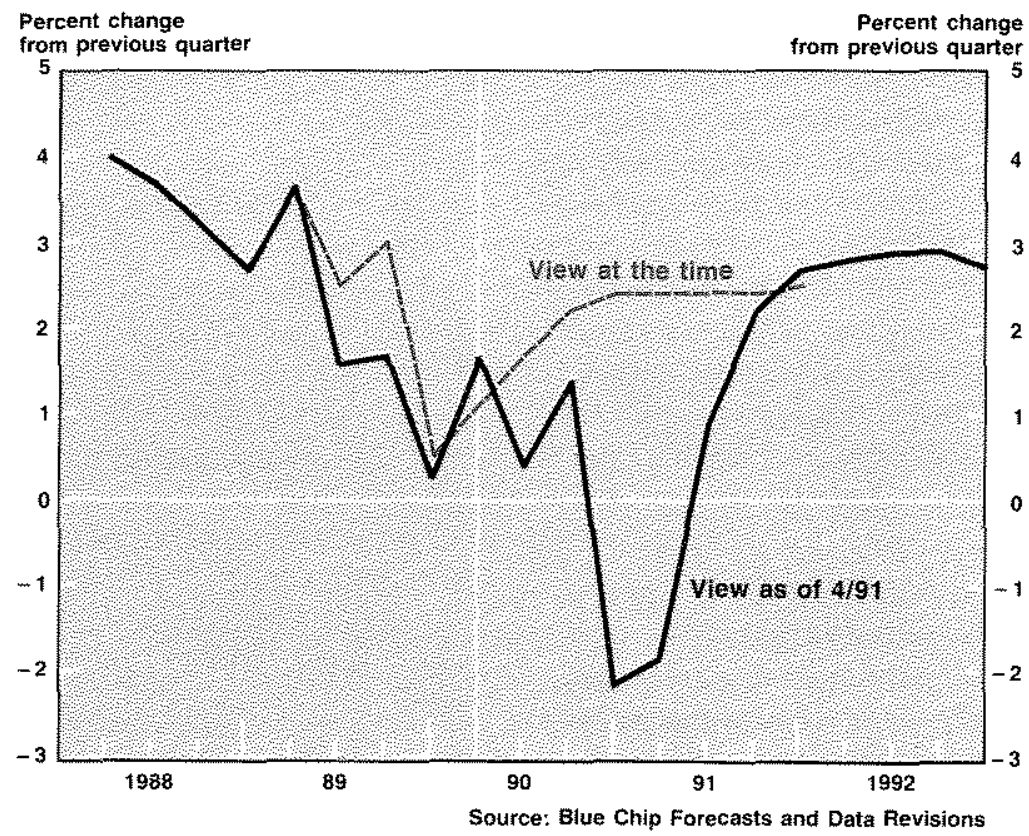

February and into March, figure 4 indicates that most of the weekly growth rates were within a range consistent with a 3 to 7 percent growth rate for the year. It does not appear, therefore, that there was any change in policy according to an M2 measure of the policy stance during the period immediately following the February meeting. Finally, figure 6 also shows little indication of a change in the thrust of policy, as reserves continued to grow. All considered, policy appeared to be steady as the Committee convened in late March.

Figure 7 indicates that the four quarters beginning April 1990, only a week after the Mareh meeting was held, appear from today's perspective to be one of the weakest sequences of quarters since 1982. Nevertheless, at the time the FOMC met, there was no indication, according to the Blue Chip Consensus, that the national economy would be entering a recession later in the year. The private forecasters' outlook for real GNP growth changed little between the February and March meetings.

The Board staff projection was qualitatively consistent with the Blue Chip forecast, suggesting "the economy was likely to expand at a somewhat faster pace over the next several quarters than in the fourth quarter of $1989 . " 43$ Growth in that quarter was reported to have been less than 1 percent at an annual rate. The Committee concurred, as "on balance ... the members viewed sustained growth in business activity as a reasonable expectation for the next several quarters," ${ }^{44}$ In addition, the Committee "expressed a great deal of concern about the apparent lack of improvement in underlying inflation trends." 45 Considering the forecast for real output, in addition to other pertinent information, the majority of the Committee voted to maintain the "current degree of pressure on reserve positions." ${ }^{46}$ No direction of intermeeting bias was specified.
43May Press Release, p. 6

44May Press Release, p. 7
45 May Press Release, p. 7.

46 May Press Release, p. 13. 
The Board staff warned at the March meeting that M2 growth might be slow or non-existent over the spring and early summer, partly for special technical reasons and partly because of the general slowing in the rate of nominal GNP growth. A number of Committee members, commenting on the Board staff report, felt a slowing in the rate of M2 growth "would be a welcome development," since it would put M2 growth more squarely within the Committee's target range. ${ }^{47}$

\section{Meeting of May 13,1990}

Figure 2 suggests that policy was steady during the period immediately following the March FOMC meeting, according to a federal funds rate measure of the policy stance. As the Board staff report predicted, however, the monetary aggregate measure tells a different story: M2 growth began to slow in March, moving toward the midpoint of the Committee's target cone by July. Figure 4 shows that annualized weekly M2 growth rates were mostly at or below the 3 percent mark in the weeks between the March and May meetings. Of course, the March staff report had predicted a slowing in $\mathrm{M} 2$ growth, and in addition, the data on monetary aggregates simply tend to be noisy. Figure 6, however, shows that reserve growth was negative between the March and May meetings, which might be construed as a relatively tight policy immediately following the March meeting. Therefore, as the Committee convened in May it was not clear by some measures that policy had been constant during the intermeeting period. By one measure, policy remained steady; by another, policy tightened beginning at about the time of the March meeting

The outlook for real GNP at the time of the May meeting, as summarized by the Blue Chip Consensus forecast, was again virtually unchanged from February 10. Generally speaking, the view at the time was much more optimistic than the view from the present. Private forecasters at the time viewed real GNP growth as being faster for virtually every quarter in 1989 , 1990 and 1991 relative to the view today. The Blue Chip Consensus indicated a virtually flat growth rate of 2 percent a quarter through 1990, increasing slightly in 1991.

The Board staff projection concurred with private forecasts, suggesting "that the economy was likely to expand at a moderate pace over the balance of the year." ${ }^{\prime \prime 8}$ In addition, the Committee "generally agreed that the current information on business conditions pointed on balance to relatively moderate but sustained economic expansion." 49 Considering the outlook for real GNP as well as other economic information, a large majority of the Committee supported a directive that called for unchanged policy with no bias toward tightness or ease. ${ }^{\text {so }}$

The Board staff explained in an analysis prepared for the Committee that M2 growth was expected to pick up somewhat before the next meeting, even under a policy of "steady reserve pressure." ${ }^{1}$ Several members com. mented that "a failure of such growth to pick up would be a matter of increasing concern" and might be taken as a reflection, among other things, of "growing constraints on the availability of credit to potential borrowers." ${ }^{52}$ Generally, however, the Committee felt it was too early to reach a definitive conclusion since the observed moderation might merely be a manifestation of the natural volatility in monetary growth rates. ${ }^{53}$

\section{Weathe of Jur 2-3, 1990}

The July meeting was the second of two during the year in which the Committee reviewed its long-term goals, including an assessment of the target cone set at the February meeting for M2 growth. According to the Record, "the Committee took account of the much slower than anticipated expansion of $\mathrm{M} 2 \ldots$ in the first half of the year. . . ${ }^{54}$ Some members noted that any "shortfall from the current ranges should be kept under careful scrutiny to judge whether

\footnotetext{
47 May Press Release, p. 12.

49. July Press Felease, p. 6.

45 July Press Release, p. 7.

50July Press Release, pp. 10-11.

51 July Press Release, p. 11. This is possible because, while a component of $\mathrm{M} 2$ is related to the monetary base by the money multiplier, M2 is a broad aggregate with many other components over which the Federal Reserve has little direct influence.
}

52 July Press Release, p. 11.
53July Press Release, p. 11.
54 August Press Release, p. 11. 
Figure 8

\section{Private Forecasters' View of Real Output,} July 1990

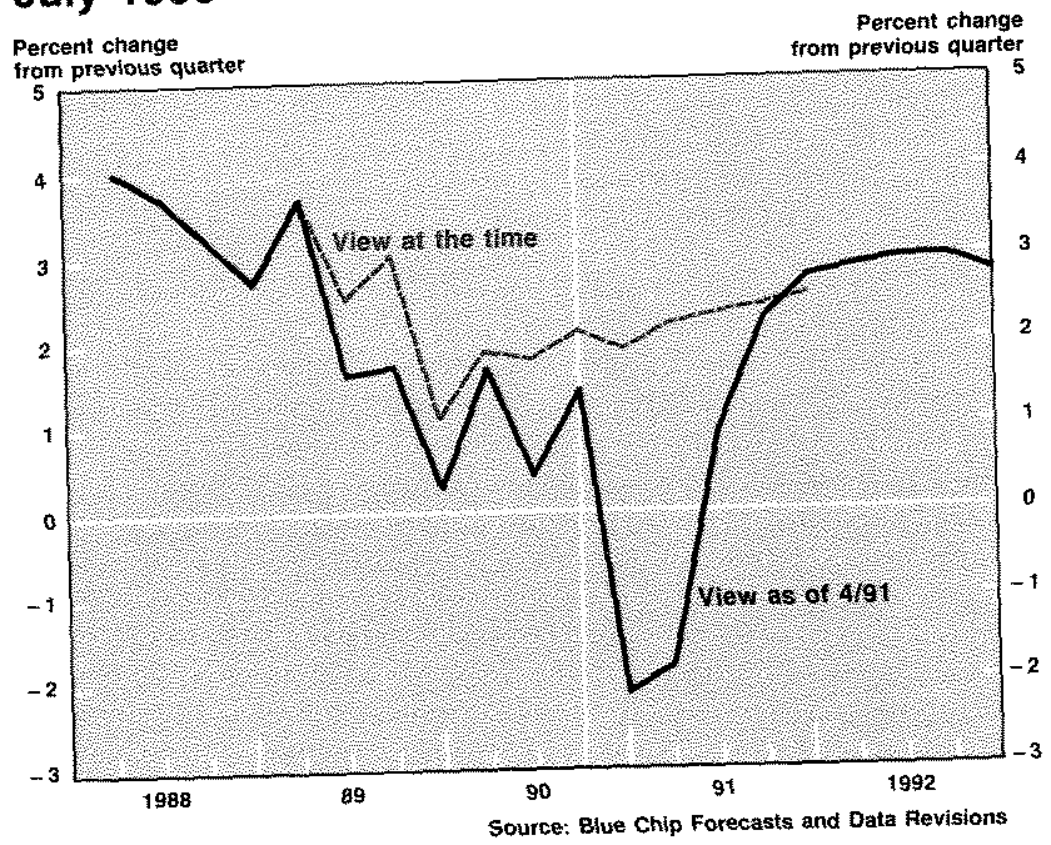

policy was indeed tighter than intended or desired." ${ }^{5}$ After this review, the Committee reaffirmed its range for $M 2$ growth at 3 to 7 percent for the remainder of $1990 .^{.56}$ One argument that played a role in this decision was that the Committee should avoid making adjustments to target cones, at least at mid-year. Some members suggested, for instance, that "the ranges should not be moved up or down to fit special circumstances. . . . ${ }^{57}$

According to the evidence from a number of countries presented in figure 1 , the decision to keep the M2 target range at between 3 and 7 percent continued to place the U.S. squarely in a group of relatively low money growth countries. This is consistent with the Committee's low inflation strategy because these are the countries that have tended to experience the lowest average inflation rates over the last 20 years. In this sense, the Committee continued to maintain its anti-inflation posture at this meeting.
Of course, in this context, "low" is relative to world standards, and the relationship between money growth and inflation is not exact even over very long time horizons.

The Committee also contemplated the policy stance for the period until the next meeting. During the intermeeting period, the federal funds rate, M2 and total reserves measures all seemed to indicate a steady policy. The Blue Chip Consensus forecast and the available data for real GNP appeared as the path represented by the boxes in figure 8 . A recession was not predicted by private forecasters at the time, and there was simply no way of knowing that Iraq would invade Kuwait during the forthcoming intermeeting period. Available actual data as well as private forecasts continued to be almost uniformly optimistic relative to the actual outcomes for quarterly real GNP growth as viewed from the present.

55August Press Release, p. 13.

56August Press Release, p. 14.

57August Press Release, p. 14 
The Board staff forecast for the remainder of 1990 was again in general agreement with the private forecasts, suggesting "the economy would expand ... at around the rate estimated for the first half of the year." ${ }^{\text {rs }}$ Committee members concurred with the Board staff and the private forecasters as they "generally saw sustained but subdued growth in economic activity as a reasonable expectation for the next several quar. ters . . [T]he economy as a whole gave no current indications of slipping into recession." ${ }^{n s}$

The forecast of slow but positive growth was buoyed, according to the Record, by a number of other factors that the Committee considered in addition to point predictions of real GNP growth. Unemployment, for example, remained at 5.3 percent in May and had been at that level for more than a year. Industrial production was up substantially in May, and economic growth seemed to be satisfactory in the major industrialized nations. ${ }^{60}$

Based on the forecasts for real GNP and the consideration of the most recent data on the state of the economy, the FOMC unanimously endorsed an unchanged policy for the seven week period until the next meeting. The majority of the Committee also favored a bias toward "some slight easing" depending on the intermeeting data on M2 growth and inflation. In particular, the majority wanted to ease slightly unless M2 growth picked up appreciably or inflation began accelerating faster than expected. ${ }^{61} \mathrm{Ac}$ cording to the Record, "the marked slowing in monetary growth in the second quarter in particular suggested the possibility of more restraint than the Committee intended."'62

Figure 9 shows the M2 data available at the time of each FOMC meeting. The crosses represent the revised data available today, while the boxes show the time path as it appeared at the time. At the July meeting, the Committee saw data suggesting a decline in M2 from the level of the previous meeting. The revised data available today show no such decline, however, and indeed generally indicate an increase over the previous 13 weeks. Data revisions can therefore explain, to some extent, the discussion in the
Record of the "marked slowing in monetary growth" when it appears from figures 3 and 4 that money growth was picking up in the weeks before the July meeting. The data revision problem for $\mathrm{M} 2$ does not seem to have been as acute for other periods during 1990.

\section{Meeting of Angust 21, 1990}

As it turned out, money growth did not pick up in the weeks immediately following the July meeting, and in mid-July "pressures on reserve positions were eased slightly."63 Measuring policy by the federal funds rate indicates that, according to figure 2 , policy did ease slightly on or about July 13 , with the rate declining to just over 8 percent by early August. The effective weekly federal funds rate later rose, however, and did not fall below the early August level until mid-October.

According to figures 3 and 4 , the growth path of M2 also seemed to indicate some ease during the intermeeting period. The annualized weekly growth rates, which are near zero or negative in the month immediately following the July meeting, are greater than 7 percent in the last three weeks leading up to the August meeting. of course, these data are noisy and interpretation is difficult. Total reserves reached a low for the year on July 25, reflecting a slight decline overall during the intermeeting period.

The invasion of Kuwait on August 2, 1990, clouded considerably the outlook for the U.S. economy for the remainder of the year and through the first half of 1991. The key economic question was the magnitude and stay. ing power of the resulting crude oil price increases. According to the Record, at the August meeting the Committee ". . focused on both the state of the economy before the increase in oil prices and the likely consequences for real output and inflation of that rise." 64

A comparison of the available data and the associated Blue Chip Consensus forecasts for July, August and September, illustrated in figures 8,10 and 11 , respectively, demonstrate the fluidity of the forecasting situation during this two-month period (July 10-September 10). First

\footnotetext{
${ }^{58}$ August Press Release, p. 6.

59 August Press Release, p. 7.

${ }^{60}$ August Press Release, pp. 1-4.

61August Press Release, p. 18.
}

62August Press Release, pp. 18-19.

63October Press Release, p. 4.

${ }_{64}^{6}$ October Press Release, p. 7. 


\section{Figure 9}

\section{M2 Data Available at FOMC Meetings}

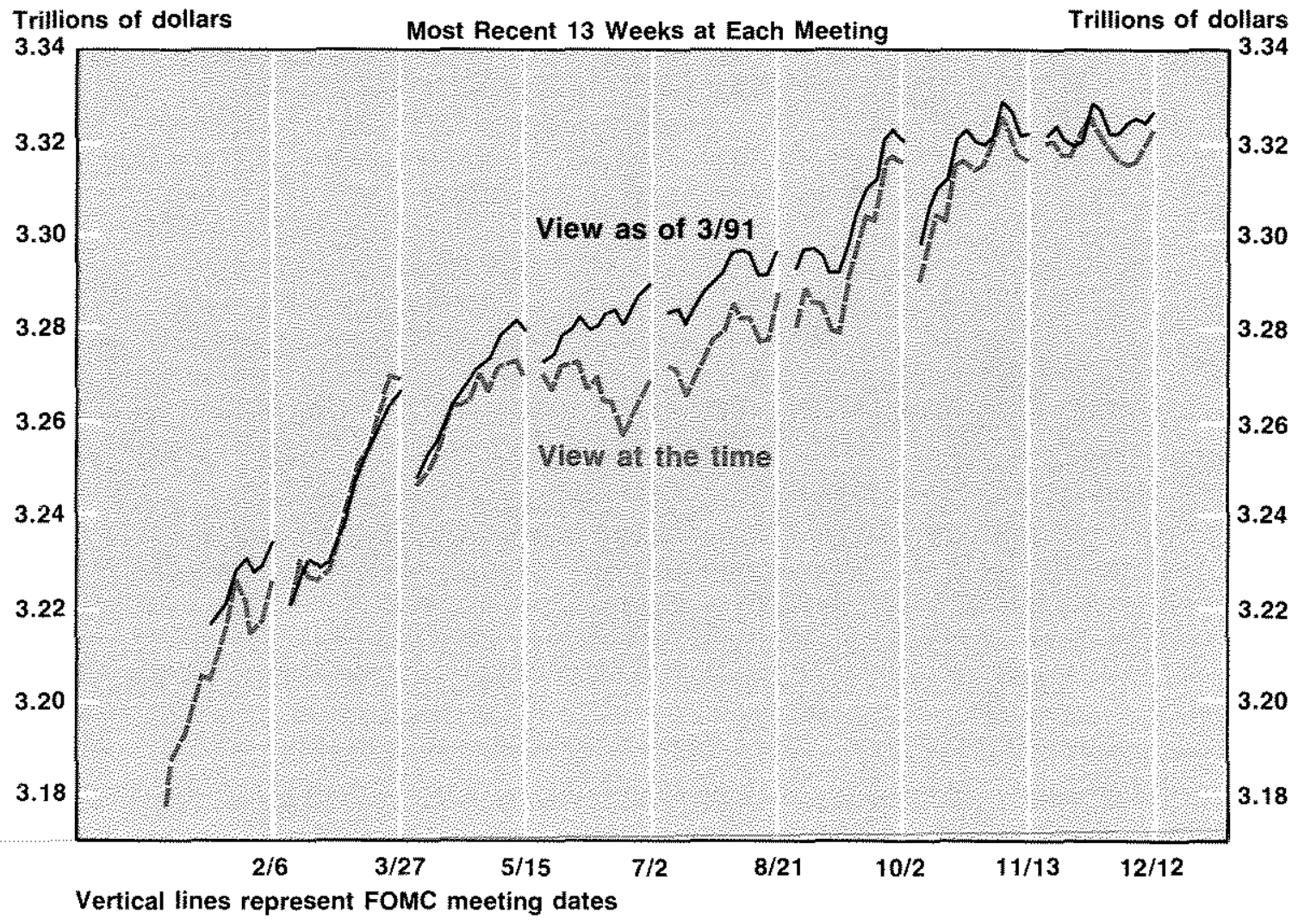

of all, in July, the data for all of 1989 and the first quarter of 1990 were revised downward, revealing greater sluggishness in real GNP growth than had previously been estimated. Secondly, the situation in the Middle East was evolving on a daily basis, and the eventual outcome simply could not be predicted. As figure 11 shows, by September 10, about three weeks after the August FOMC meeting, the Blue Chip survey put the consensus forecast for real GNP growth at zero for the fourth quarter of 1990; this reflects a downward revision for fourth quarter output growth from over 2 percent as the year began.

Once again, the Board staff projection reflec- ted that of the private forecasters. While the staff "recognized that the recent steep rise in oil prices could have important adverse effects . . . [It also recognized that] it was not possible to. determine with any confidence how oil prices might evolve over time. . . ."65 Nevertheless, it seemed to the staff that slow expansion of real output was likely over the balance of the year, albeit at a reduced rate from that previously projected. ${ }^{66}$ The staff forecast was based, in part, on substantial growth in exports in the quarters that lay ahead, because foreign industrial economies were viewed as relatively strong and a considerable depreciation had already occurred in the foreign exchange value of the dollar. ${ }^{67}$ 
Figure 10

Private Forecasters' View of Real Output, August 1990

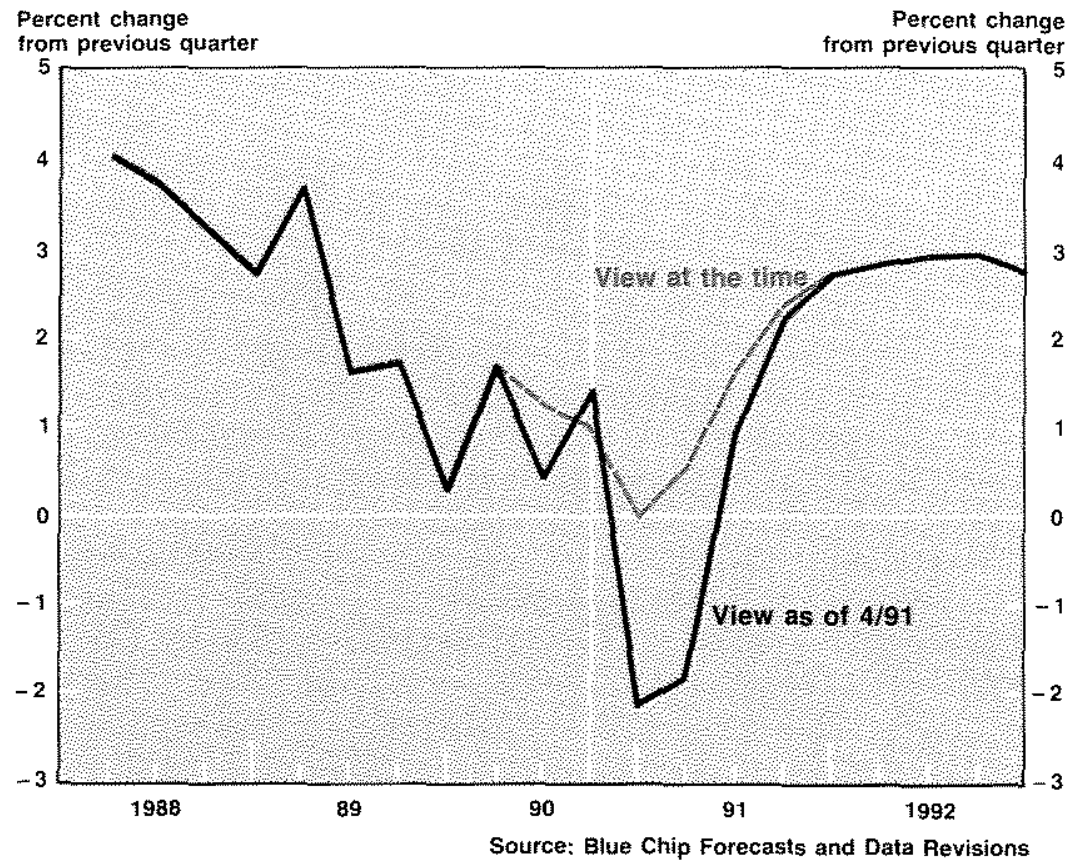

Figure 11

Private Forecasters' View of Real Output, September 1990

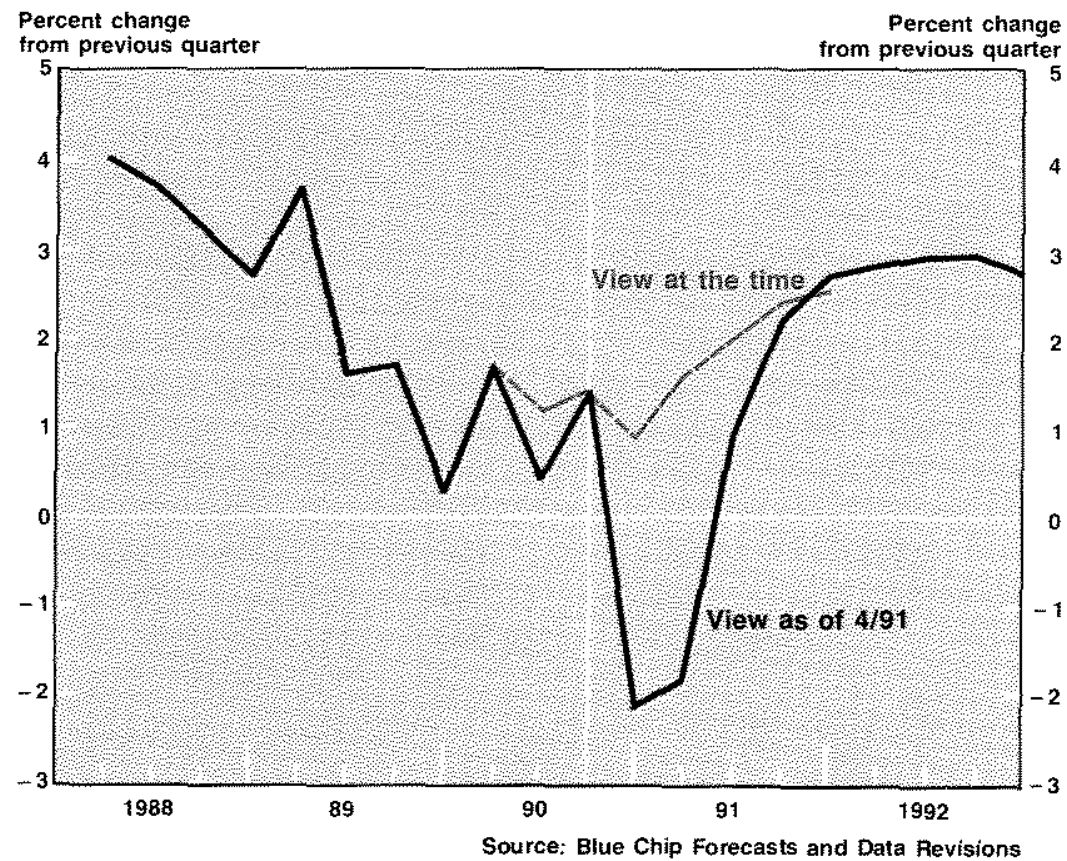


FOMC members again concurred with the staff and private forecasters that "limited growth in economic activity remained a reasonable expectation."'6s The Committee recognized that most of the available data on the economy pertained to a period before the Iraqi invasion. The Record notes that unemployment rose from 5.3 percent to 5.5 percent in July and that domestic industrial production was flat. Overseas, real output growth in both Japan and Germany remained robust. In addition, the trade-weighted value of the dollar had fallen substantially dur. ing the intermeeting period in terms of other G-10 currencies. ${ }^{69}$

In the Committee's view, the oil price shock would tend to "weaken economic activity while also intensifying inflationary pressures. ${ }^{\prime \prime 70} \mathrm{Com}$ mittee members tended to see changes in policy as counterproductive, an easing probably fueling inflation, a tightening probably stalling a weak economy. ${ }^{71}$ Accordingly, the Committee elected to maintain the current policy stance, "fostering a stable policy environment." But sev. eral members stated that they wanted "to avoid any paralysis of policy ... in the weeks ahead." Some saw a likely need to ease "at some point," weighed against continuing decline in the dollar in markets for foreign exchange. ${ }^{72}$ Therefore, while there were "some differences in views," the majority of the Committee membership supported a bias toward ease in the intermeeting period. ${ }^{73}$

\section{Merting of Dchober. 1990}

According to the Record, the bias in the directive was not acted on in the intermeeting period because inflation was "not abating and the economy [was] continuing to advance, albeit slow. 1y. . ." Measures of the policy stance in the weeks immediately following the August meeting, in general ${ }_{\text {s }}$ seemed to indicate a steady policy without any bias toward ease. As figure 2 indicates, federal funds traded at $8-8.25$ percent over the period, which represented no change from the previous intermeeting period. Total reserves grew somewhat during the intermeeting period. Money by an M2 measure displayed, according to figure 4 , considerable volatility in annualized weekly growth rates in the weeks following the August meeting, to the point where an assessment of the intermeeting policy stance by this measure is quite difficult.

The private forecasts for July, August and September indicate rapidly deteriorating expectations for real output. Still, no recession was forecast at the time of the August meeting-or even three weeks later on September 10-and the private forecasters appeared to view the slow growth as temporary, predicting annual. ized gains in real GNP of more than 2 percent by the third and fourth quarters of 1991 . The October meeting of the FOMC occurred eight days before the Blue Chip Consensus forecast illustrated in figure 12 was officially released. October, the first month of the fourth quarter, was the first time this set of forecasters envisioned negative growth on the horizon. By October 10 , the Blue Chip Consensus forecast was actually two consecutive quarters of negative growth in real GNP-mut just barely. A recession was not definitively predicted by Blue Chip until November. ${ }^{75}$

Figure 13 illustrates the dramatic change in the outlook for real GNP as forecast by the Blue Chip Consensus from July 1990 to October 1990. In the space of only three months, the forecast changed from one of sluggish but increasing rates of real growth to near zero and even neg. ative growth rates. In terms of time for policy reaction, this change was quite fast. If one accepts research evidence that monetary actions affect real activity only with a lag of several quarters, this rapid deterioration in the expected performance of real output underscores the difficulty of making timely short-run adjust. ments in the stance of policy.

The Board staff, acknowledging a great deal of uncertainty linked to developments in the Middle East, projected "a mild downturn in economic activity ... for the near term." ${ }^{176}$ The staff

\footnotetext{
68 October Press Release, p. 8.

${ }^{9}$ October Press Release, pp. $1+3$.

70 October Press Release, p. 11.

7 October Press Release, pp. 11-12.

72 October Press Release, p. 12.

73October Press Release, pp. 13-14 and p. 16.

${ }^{74}$ November Press Release, p. 4.
}

75 See the Blue Chip Economic Indicators, October 10 and November 10, 1990. The October consensus forecast called for two consecutive quarters of negative real GNP growth, but the second of these quarters was nearly flat.

76 November Press Release, p. 6. 
Figure 12

Private Forecasters' View of Real Output, October 1990

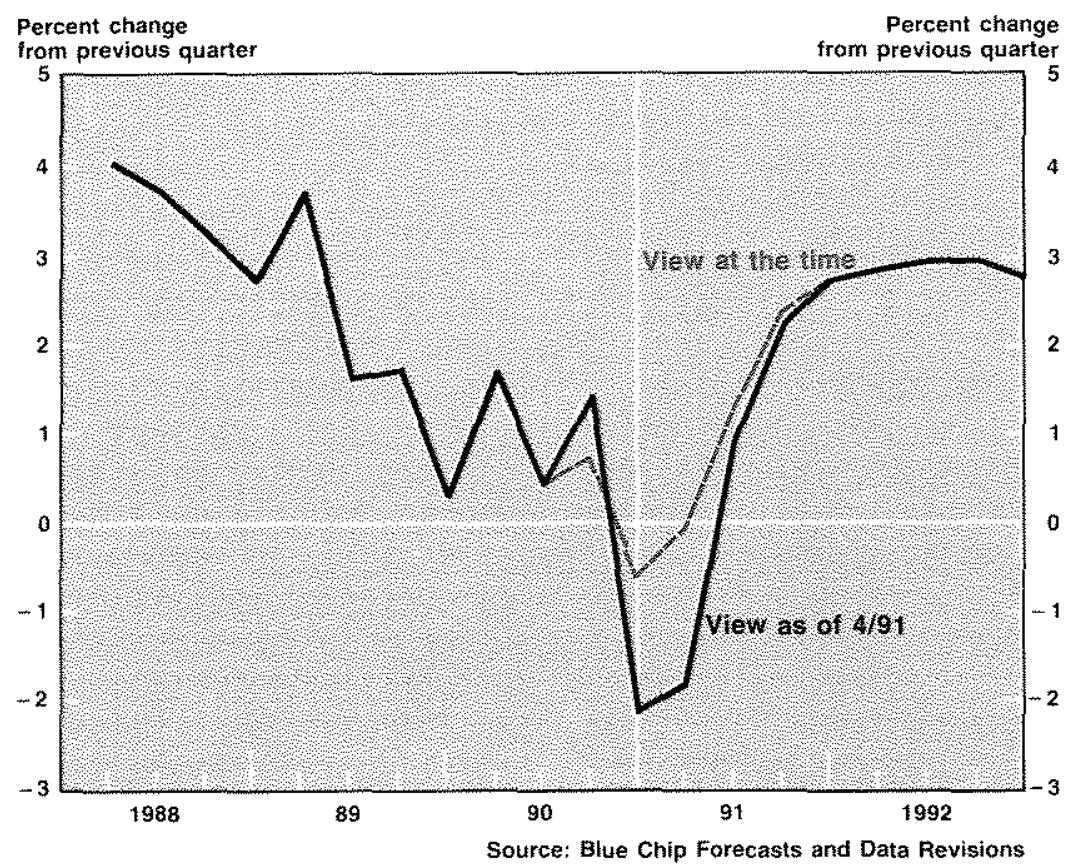

Figure 13

Private Forecasters' Changing Perceptions

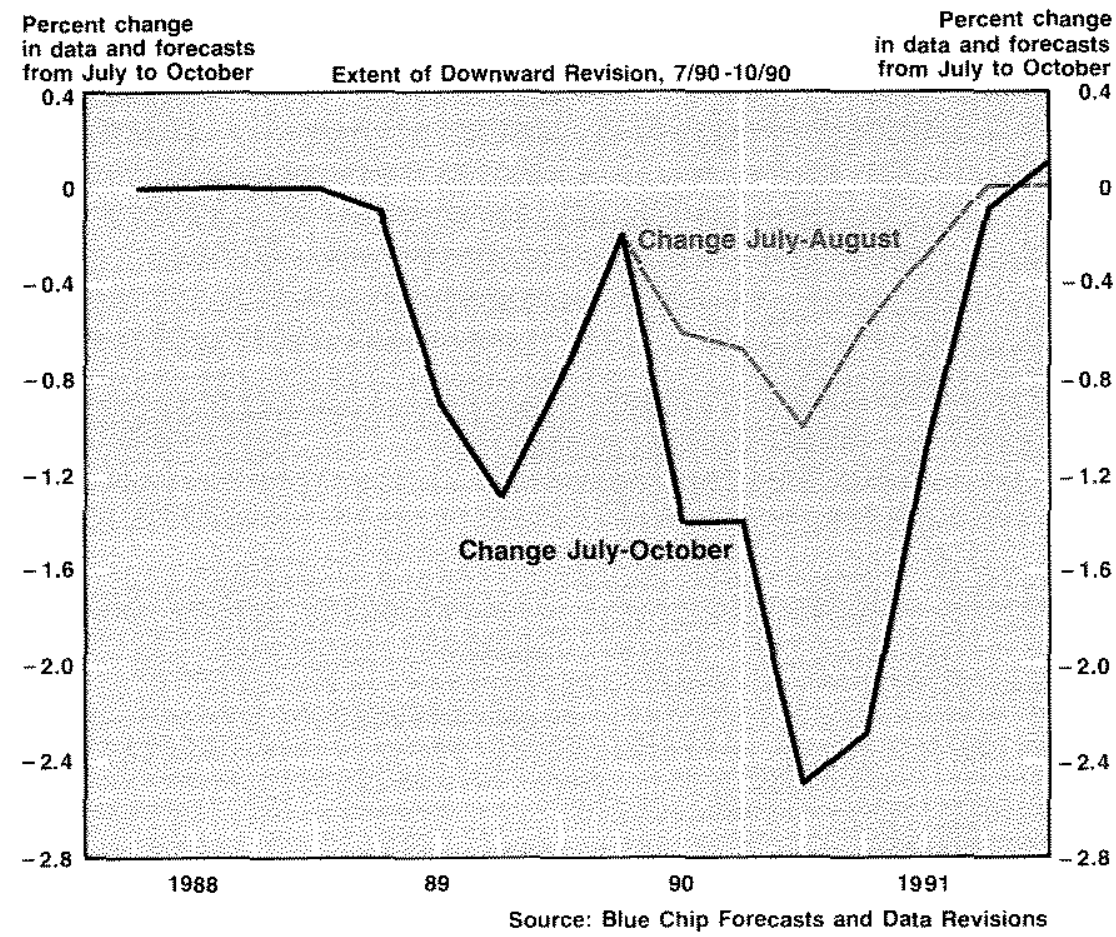


continued to see strong exports as a mitigating factor, propelled by the projection of continuing growth in several other major industrialized nations, especially Germany and Japan. The staff forecast also relied to some extent on a drop in oil prices during the first half of $1991 .{ }^{77}$

For the first lime in 1990, the FOMC membership dissented qualitatively from both private forecasters and the Board staff in their view of the likely future path of real output. The Record reports a sense of the meeting concluding that, while the Committee felt the risk of negative real output growth had increased, "overall economic activity appeared to be continuing to expand, although at a slow pace. . . IT] The avail. able data did not point to cumulating weakness and the onset of a recession." were concerned that surveys of business confidence seemed to indicate a declining faith in a continued expansion, while traditional indicators continued to suggest sluggish growth. ${ }^{79}$ Some members suggested that inflation was getting worse even after accounting for the effect of higher crude oil prices. ${ }^{80}$ According to the Record, "A major concern was that the rise in oil prices would become . . firmly entrenched in the cost structure of the economy . . . and Idelayl progress toward price stability." ${ }^{\prime 1}$ Nevertheless, most members felt that "an easing move was warranted in light of the indications that there was a significant risk of a much weaker economy." 82

The Committee also expressed concern about an easing in response to the impending budget deal being erafted by Congress and the White House. The timing of any move needed to be considered carefully, as action before any budget accord might create the expectation of more action after the deal was struck ${ }^{83}$ In the discussion, some members suggested that "associating an easing move too closely with a fiscal policy action might set an undesirable precedent in terms of producing expectations of similar monetary policy adjustments in the future." 84 The advocates of easing on the Committee agreed that the "reasons for the easing were not keyed to the enactment of the new federal budget alone but more broadly to developments in credit markets and the economy. . . "ss The crux, according to the Record, was simply that "market participants expected a monetary policy response to the fiscal policy actions. . . " $" 86$

The Committee issued an unusual directive in response to the concerns about declining output, accelerating inflation and fiscal policy. The directive called for no change in the degree of pressure on reserve positions initially, but assumed "some slight easing would be implemented in the intermeeting period, assuming passage of a federal budget resolution . . . and the $a b$ sence of major unexpected . . developments."sz Thus, the directive was biased toward ease. However, the Record indicates that an additional proviso was added; in particular, the Committee agreed to ease further if real output showed further signs of deterioration. ${ }^{88}$ The Record also notes that "some slight firming" was not ruled out, should inflation appear to pick up. ${ }^{89}$

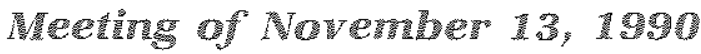

During the intermeeting period, policy was initially unchanged. The contingencies in the directive were exercised late in October, when "pressures on reserve conditions were eased slightly." The Record cites both the "background of a weakening economy" and "the conclusion of a budget agreement" as factors influencing the decision and the timing of the easing. ${ }^{90}$ Other indicators of the thrust of policy, however, do not provide evidence of an easing during the weeks leading up to the November meeting. The weekly average federal funds rate, plotted in figure 2 , had drifted up to a level near 8.25 percent by the time of the October meeting. As the figure shows, federal funds had been trading near 8.25 percent for most of the year, except for the period immediately follow ing the mid-July easing. The rate had fallen to a

\footnotetext{
${ }^{77}$ November Press Release, pp. 6-7.

78November Press Release, p. 7.

79 November Press Release, p. 10.

aoNovemper Press Retease, pp. 11-12.

an November Press Release, p. 12

a2November Press Release, $p .12$.

83November Press Release, pp. 13-14.

84November Press Release, p. 14.
}

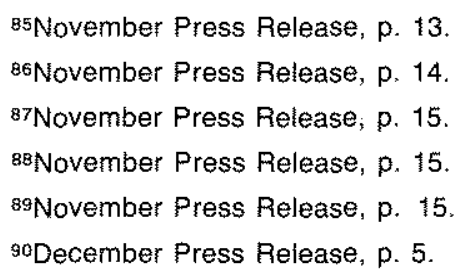


point just below its early August level during the intermeeting period. Based on a cursory look at the level of the federal funds rate, therefore, the policy stance seemed to be about the same as it was after the mid-July easing, ${ }^{91}$ Total reserves fell substantially between the October and November meetings, suggesting a tight policy instead of an easy one. Finally, beginning at about the time of the October meeting, M2 growth nearly slowed to a standstill, reaching a level it would not again attain until the final weeks of 1990. Figure 4 indicates that most of the annualized weekly growth rates for the remainder of the year were below 3 percent, and many were negative. By an $\mathrm{M} 2$ indicator, then, policy tightened considerably in the fourth quarter. ${ }^{92}$

Private forecasters, as surveyed by Blue Chip, reached a consensus view that the economy was entering a recession in November, according to the forecast illustrated in figure 14. Relative to current projections, however, the forecast remained optimistic about the depth of the downturn. The Board staff also projected a mild recession with recovery occurring in the first half of 1991. The staff assumed a drop in crude oil prices early in 1991 and export growth driven by the expansion in foreign industrialized nations. The staff forecast also emphasized the uncertain environment prodded by the military standoff between the U.S. and Iraq on the Kuwaiti border. ${ }^{33}$

The FOMC membership saw a relatively mild recession ahead, thus establishing general qualitative agreement with private forecasters and the Board staff. They also viewed a slow expansion in 1991 as a reasonable expectation. ${ }^{94}$ Accordingly, the Committee agreed to some slight easing immediately and to some bias toward further easing during the intermeeting period. Whether the option to ease further was exer. cised depended in part on "market reactions to the initial action. . . .

The November directive of the FOMC is the first to indicate a substantial commitment to

91According to the Record, the reason federal funds traded at 8.25 percent early in the intermeeting period was "more cautious feserve management policies at some banks and some carryover of end-of-quarter pressures. ..." See the December Press Release, p. 5.

92By the November meeting, "the recent weakness in monetary growth was becoming a matter of increasing concern and was an important consideration for some members in their support of some easing of reserve conditions." See the December Press Release, p. 12. ease. At the time of the November meeting, the economy was in the middle of what appeared to be the onset of recession. No amount of easing was likely to change fourth-quarter real output -industrial production was already in the midst of dropping 19.8 percent on an annualized basis in November. Instead, according to the Record, the Committee viewed the easing as providing "some insurance against a deep and prolonged recession. ...."96

\section{Meeting of December 12.13, 1990}

As the Committee convened in mid-December, the indicators of policy were again sending conflicting signals. In the period between the November and December meetings, the federal funds rate dropped substantially, suggesting dramatic easing relative to earlier actions (see figure 2). As reflected in figure 6 , however, the data on total reserves pointed instead to a fur. ther tightening of policy, as the previous negative intermeeting growth rate is followed by a steeper decline in reserves after the November meeting. The annualized weekly growth rates of M2 plotted in figure 4 also do not offer evidence of substantial ease during this period. Money growth simply continued at a near zero pace, on average, through to the December meeting.

Figure 15 reflects the outlook for real GNP at the time of the FOMC's December meeting. The assessment of the private forecasters in the Blue Chip survey continued to grow more pessimistic by the month. In fact, one of the striking features of the evolution of Blue Chip forecasts in 1990 is that they farly consistently over. predicted real output growth.

The Board staff continued to project a mild recession with a rebound before mid-year $1991 .^{97}$ Committee members concurred that a short downturn followed by modest recovery seemed reasonable, but they emphasized the risks of a prolonged downturn. Some Committee members also recognized, however, the possibility of pro- 930ecember Press Release, pp. 6-7.

${ }^{94}$ December Press Release, p. 8.

950ecember Press Release, p. 13.

960ecember Press Release, p. 12.

${ }^{97}$ February Press Release, p. 6. 
Figure 14

Private Forecasters' View of Real Output, November 1990

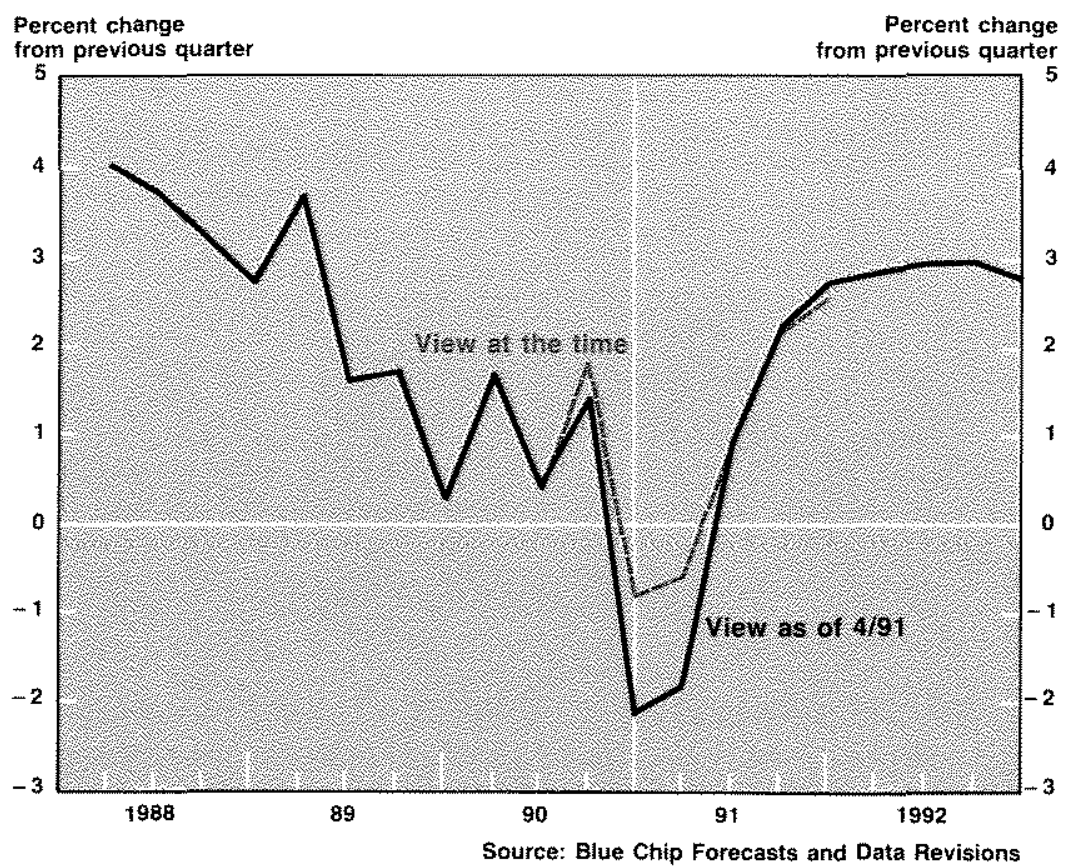

Figure 15

Private Forecasters' View of Real Output, December 1990

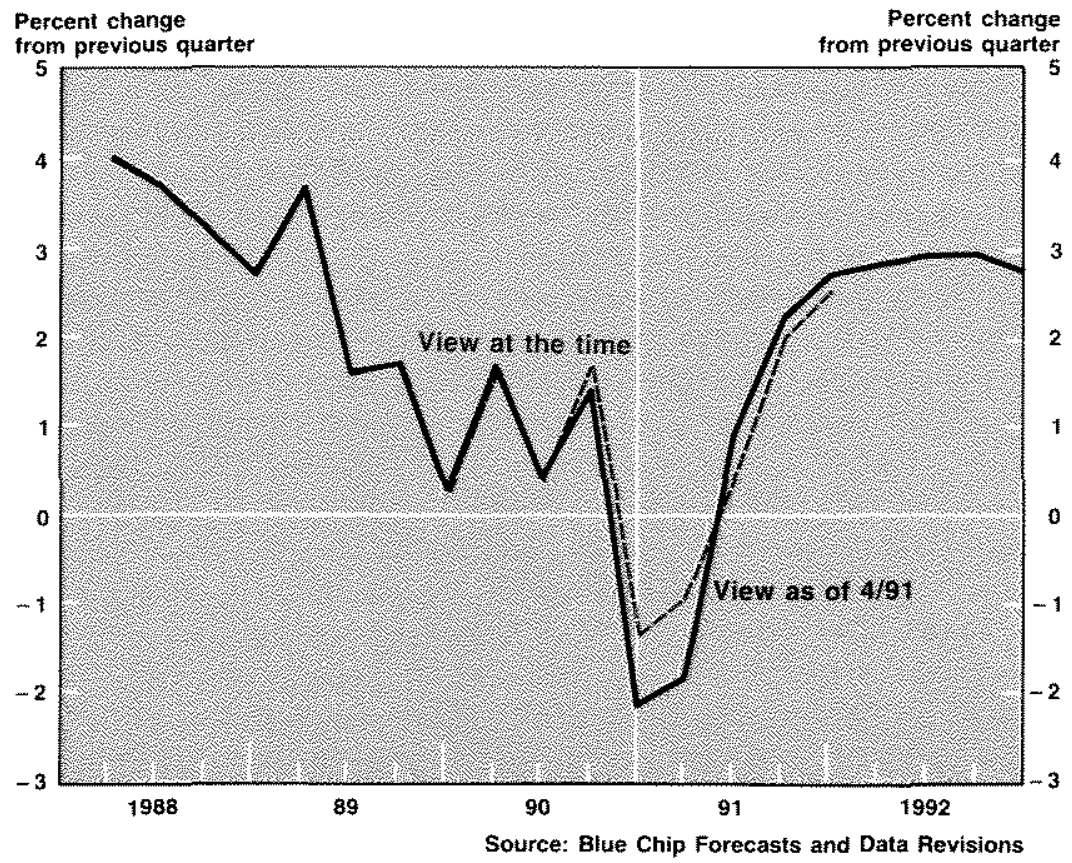


cyclical policy, noting that because of "the lags involved, there was some risk of overdoing the easing of policy at some point. . . ." Neverthem less, members unanimously supported additional easing in the directive in order to "provide some added insurance in cushioning the economy against the possibility of a deepening reces. sion and an inadequate rebound."

In the woeks following the December meeting, policy indicators suggested that further easing occurred, if one considers a federal funds rate measure of the policy stance. In particular, the rate dropped to 6.25 percent by the time of the February 1991 meeting. In addition, the inter. meeting growth rate of total reserves plotted in figure 6 seems also to indicate dramatic easing, as reserves increased nearly 25 percent on an annualized basis from the December meeting. There was little evidence of $\mathrm{M} 2$ growth in the weeks immediately following the December meeting, but then the aggregate began to show substantial growth beginning in late January 1991. ${ }^{100}$ By an M2 measure, policy remained tight through the first weeks of 1991 before indicating signs of ease. All measures seemed to indicate ease by the first week of February 1991.

\section{SUMMARE}

This article has presented a case study of FOMC actions during a year in which a recession began. The Committee states its goals in each directive, and they are to provide for stable prices and to promote sustained real output growth. The article has emphasized, within the context of a chronology of 1990 FOMC policymaking, some problems of implementing a policy to meet these stated objectives.

Evidence is presented early in the article regarding the relation between money growth rates and inflation rates across countries and time. An argument is made that over very long time periods, average inflation tends to reflect average rates of money growth. If this evidence is used as a guide, the Federal Reserve in 1990 recorded stellar success in maintaining growth rates of money stocks that are much lower than those achieved by many other central banks. Coupled with other similar decisions over a long period, this will continue to place the U.S. in a small group of countries that will likely continue to experience, relative to other countries in the world, very low inflation rates. This article has provided, therefore, one interpretation of the FOMC's "long-run, anti-inflation strategy" sometimes cited in the Record. ${ }^{201}$

The FOMC's ability to achieve its real output objective is hampered, however, by the diffi. culty of forecasting real output changes far enough ahead to take corrective action. The article assessed the information available on the projected evolution of real output at the meetings by presenting the unrevised data available at the time along with the most cument Blue Chip Consensus forecast. According to the Record, the Committee's views rarely differed substantially, at least qualitatively, from the private sector forecast. This, along with evidence in the Record, indicates that a negative quarter of real output growth was not anticipated until October, and a recession forecast did not come until November, already well into the first quarter of the downturn.

Another feature of short-run policymaking is that it requires some measurement of the mone. tary policy stance. This article has emphasized how different indicators on some occasions im. ply different assessments of the thrust of monetary policy. In particular, the total reserves and M2 indicators suggested that policy was tight in the fourth quarter, while an interest rate indicator suggested the opposite. By the first quarter of 1991, however, all measures suggested that the policy stance had shifted toward ease in response to the onset of recession.
${ }^{98}$ February Press Release, p. 12.

99February Press Release, p. 12.

1caCommittee members showed concern for the flat growth in $\mathrm{M} 2$ at the December meeting. The Record suggests that while "the behavior of $M 2$ was not fully understood," it might be due to caps on credit availability as well as the weak growth of the economy. See the February Press Release, p. 13.

10 August Press Release, p. 13. 


\section{TERTRENCES}

Bernanke, Ben, and Alan Blinder, "The Federal Funds Rate and the Channels of Monetary Transmission," NBER Working Paper No. 3487 (October 1990).

Blanchard, Olivier Jean. "Why Does Money Affect Output? A Survey" in Benjamin M. Friedman and Frank H. Hahn, eds., Handbook of Monetary Economics, Volume II (NorthHolland, 1990), pp. 780-835.

Blue Chip Economic Indicators, 1990 issues.

Christiano, Lawrence J., and Lats J. Ljungqvist. "Money Does Granger-Cause Output in the Bivariate Money-Output Relation," Journal of Monetary Economics (1988), pp. 217-35.

Dwyer, Gerald P., Jf and A. W. Hafer. "Is Money Irrelevant?" this Review, (May/June 1988), pp. 3-17.

Federal Reserve Press Releases, Record of Policy Actions of the Federal Open Market Committee, dated March 30 , 1990: May 18, 1990; July 6, 1990; August 24, 1990; October 5, 1990; November 16, 1990; December 21, 1990; and February 8, 1991.

Hallman, Jeffrey J., Richard D. Porter, and David $H$. Small. "M2 Per Unit of Potential GNP as an Anchor tor the Price Level," Staff Study 157 (Board of Governors of the Federal Reserve System, April 1989).

Karamouzis, Nicholas, and Raymond Lombra."Federal Reserve Policymaking: An Overview and Analysis of the Policy Process:" Carnegie-Rochester Conference Series on Public Policy (Spring 1989), pp. 7.62.

Laidler, David E. W. The Demand for Money: Theories, Evidence, and Problems (Harper and Row, 1985).
Lucas, Robert E., Jr. "Two Illustrations of the Quantity Theory of Money," American Economic Review (December 1980), pp. 1005-14.

"Adaptive Behavior and Economic Theory," in Robin M. Hogarth and Melvin W. Reder, eds., Rational Choice: The Contrast Between Economics and Psychology, (University of Chicago Press, 1987), pp. 217-42.

Mankiw, N. Gregory, and M. G. Shapiro. "News or Noise? An Analysis of GNP Revisions," Survey of Current Business (May 1986), pp. 20-25.

Meltzer, Allan H. "Limits of Short-Run Stabilization Policy," Economic Inquiry (January 1987), pp. 1-14.

:"The Fed at Seventy.Five," in Michael T. Belongia, ed., Monetary Policy on the 75th Anniversary of the Federal Reserve System (Kluwer Academic Publishers, 1991), pp. 3-104.

1997 Monetary Policy Objectives: A Summary Report of the Federal Reserve Board.

Papademos, Lucas, and Franco Modigliani. "The Supply of Money and the Control of Nominal Income," in Benjamin $\mathrm{M}$. Friedman and Frank $\mathrm{H}$. Hahn, eds., Handbook of Monetary Economics, Volume 1, (North-Holland, 1990), pp. 399-494.

Stock, James H., and Mark W. Watson. "Interpreting the Evidence on Money-Income Causality," NBER Working Paper No. 2228 (April 1987).

Vogel, Robert $C$. "The Dynamics of Inflation in Latin America, 1950-1969," American Economic Review (March 1974), pp. 102-14. 